\title{
Response of Rice and Carbon Emission to Application of Ameliorant Dregs in The Peat Soil with Saturation and Unsaturation Condition
}

\author{
Nevia \\ Department of Agrotechnology, faculty of Agriculture, Riau University. Indonesia \\ E-mail:nnelvia@yahoo.co.id
}

\begin{abstract}
Fertility of peat land is very poor and makes it not suitable for crop without any high input. This condition was indicated by the very high soil acidity ( low pH), low availability of macro (N, K, Ca and P), and micro (Cu, Zn, Mn and Bo) nutriens and high cation exchange capacity (CEC) but low base saturation (BS), the presence of toxic organic acid. The main organic acids, as a result of lignin biodegradation and the sources of C-release, are of aromatic group consisting mainly of derivate phenolic acids. The peat soil material was taken at depths from 0 to $30 \mathrm{~cm}$, with weathering rate saprik and dregs from Indah Kiat Pulp and Paper at Perawang, Riau. These experiments using split plot design, the main plot is the condition of the water (unsaturated and saturated) and the subplot is ameliorant dregs consisting of 4 levels $(0,10,15$ and 20 ton ha-1), each combination was repeated 4 times. The activities were focused on the interaction of water condition and ameliorant dregs, and its influences to growth and yield of rice, C-emission (CO2 and CH4). The results showed that the aplication of dregs improves plant growth and increase the yield of rice (weight of dry milled grain) compared without dreg both at unsaturated condition and saturated conditions. The Cabon-release in the forms of $\mathrm{CO2}$ and CH4 fluxes in saturated conditions is smaller than unsaturated conditions. The application dreg $10 \mathrm{t}$ ha-1 increase the number of productive tillers and the weight of milled rice about 35 and $75 \%$ compared without dreg on saturated condition, whereas the increase is greater unsaturated conditions about 63 and $80 \%$. The application of dregs $10 \mathrm{t}$ ha-1 in saturated condition can reduce $\mathrm{CO} 2$ and $\mathrm{CH} 4$ emissions about $18.19 \%$ and $93.71 \%$ compared without dreg, otherwise the application dreg 10-20 $t$ ha-1 increase the production of $\mathrm{CO} 2$ and $\mathrm{CH} 4$ in unsaturated conditions.
\end{abstract}

Keywords - PutRice, peat soil, ameliorant dregs, CH4 and CO2 emission, saturated, unsaturated condition

\section{INTRODUCTION}

This document is a template. An electronic copy can be downloaded from the conference website. For questions on paper guidelines, please contact the conference publications committee as indicated on the conference website. Information about final paper submission is available from the conference website.

Indonesia has 188 milion ha land, including peatland about 20.9 million ha, (Wahyunto et al., 2005). Peatland fertility is very poor and makes it not suitable for crop without any high input. This condition was indicated by the very high soil acidity (low $\mathrm{pH})$, low availability of macro $(\mathrm{N}$, $\mathrm{K}$, $\mathrm{Ca}$, and $\mathrm{P}$ ), and micro ( $\mathrm{Cu}, \mathrm{Zn}, \mathrm{Mn}$ and $\mathrm{Bo}$ ) nutriens and high cation exchange capacity (CEC) but low base saturation (BS), and the presence of toxic organic acid (Simbolon, 2009).

The main organic acid, as a result of lignin biodegradation and the sources of C-release, are of aromatic group consisting mainly of derivate phenolic acids. The concentration of such organic acids ranging from the highest to lowest is as follows: ferulic acid $\approx$ synapic acid $>$ pcoumaric acid > p-hydroxybenzoic acid > vanilic acid > syringic acid (Sabiham, 2010). Phenolic acids are more phytotoxic for plants and causes stunted plant growth (Tsutuski, 1984; Stevens, et al., 1994; Dohong and Sabiham, 2001), influence the biochemical and physiological processes of plants and nutrients uptake by plant (Driessen, 1978 ).

The drying and wetting processes on the peat materials affected the stability of organic acids, wich was indicated by loss of $\mathrm{C}$ - through $\mathrm{CO}_{2}$ and $\mathrm{CH}_{4}$ releases. The release of $\mathrm{CO}_{2}$ and $\mathrm{CH}_{4}$ from fibric peat was higher than that from hemic and sapric peats (Sabiham, 2010). Yagi and Minami (1990) reported that the highest rate of $\mathrm{CH}_{4}$ emission during cultivation period $\left(44.8 \mathrm{~g} \mathrm{CH}_{4} \mathrm{~m}^{-2}\right)$ was in rice field consisting peat.

The drainage of peat release oxigen $\left(\mathrm{O}_{2}\right)$ into the surface, with promotes decomposition. Emission estimates, for land use systems with a depth of $60 \mathrm{~cm}$ drainage is around $55 \mathrm{Mg}$ $\mathrm{CO}_{2}$ ha $^{-1}$ year $^{-1}$ (Hooijier et al. 2010), based on a linear relationship between depth of water table and emissions. 
Phenolic acids and C-release could be reduced to the granting of polivalen cations such as $\mathrm{Al}, \mathrm{Fe}, \mathrm{Cu}, \mathrm{Zn}$ and $\mathrm{Mn}$, thus reducing the bad effects. Where the stability of complexes between humic acid-metal getting weaker in the order of $\mathrm{Al}^{3+}>\mathrm{Fe}^{3+}>\mathrm{Cu}^{2+}>\mathrm{Mn}^{2+}>\mathrm{Zn}^{2+}>>\mathrm{Mg}^{2+}>\mathrm{Ca}^{2+}$ (Tan, 2003). Nelvia (2009) reported that application of ameliorant $\mathrm{Fe}^{3+}$ and rock phosphates containing high $\mathrm{Fe}$ cation increased the stability of peat soil and reduced the carbon loss around $1.7 \mathrm{Mg}$ of $\mathrm{C} \mathrm{ha}^{-1}$ year $^{-1}(64 \%)$ in $5 \mathrm{~cm}$ of saturated condition, $1.3 \mathrm{Mg}$ of $\mathrm{C} \mathrm{ha}^{-1}$ year $^{-1}$ (58\%) in two times of field capacity condition and $1.0 \mathrm{Mg}$ of $\mathrm{C} \mathrm{ha}^{-1}$ year $^{-1}$ $(41 \%)$ in field capacity condition.

Dregs is the precipitate formed from liquid clarification process in the pulp mill recovery and no longer useful for the pulping process. Nelvia et al. (2008) reported that dregs contain polivalen cations such as $\mathrm{Al}, \mathrm{Fe}, \mathrm{Cu}, \mathrm{Zn}, \mathrm{Mn}, \mathrm{Mo}$, and also contains other nutrients such as $\mathrm{P}, \mathrm{K}, \mathrm{Ca}$, and $\mathrm{Mg}$, the application of 15 tons dregs / ha of peatlands increases stover dry weight, dry weight of corn kernels per ear, 1000 grain weight seeds respectively $127 \%, 35 \%$ and $40 \%$ compared without dreg. This research aimed to study the potential of using dregs to reducing C-release $\left(\mathrm{CO}_{4}\right.$ and $\left.\mathrm{CH}_{4}\right)$ and increasing growth and yield of rice on peat soil in unsaturation and saturation.

\section{MATERIAL AND METHODS}

This research was conducted from July to December 2010 in a greenhouse of Agriculture Faculty of Riau University. Soil chemical properties of peat soils materials and dregs was analyzed at soil laboratory of Soil Research Bogor. The peat soil material was taken at depths from 0 to $30 \mathrm{~cm}$, with weathering rate saprik and dregs from Indah Kiat Pulp and Paper (IKPP) at Perawang, Riau.

The peat soil material was taken at depths from 0 to 30 $\mathrm{cm}$, with weathering rate saprik at Kerumutan village, Pelalawan Regency, Riau Province, while dregs from from Riau Indah Kiat Pulp and Paper (IKPP) at Perawang, Riau, dregs chemical properties can be seen in Table 1. These experiments using split plot design, the main plot is the condition of the water (unsaturated and saturated) and the subplot is ameliorant dregs consisting of 4 levels $(0,10,15$ and 20 ton $\mathrm{ha}^{-1}$ ), each combination was repeated 4 times.

Implementation of research: peat soil material equivalent of $2 \mathrm{~kg}$ dry weight oven $105{ }^{\circ} \mathrm{C}$ and drges was mixed with appropriate treatment and then incubated at saturation and unsaturation condition for 1 month and then the IR-64 variety rice was planted. Basic fertilizers: Urea, TSP, and $\mathrm{KCl}$ each with a dose of 350,150 , and $150 \mathrm{~kg} \mathrm{ha}^{-1}$ respectively.

To measure the flux of $\mathrm{CO}_{2}$ and $\mathrm{CH}_{4}$, a chamber for trapping the gases made from the fiberglass with the size of $0.75 \mathrm{~m} \times 0,20 \mathrm{~m} \times 0,20 \mathrm{~m}$, was used Syringes were used to take the samples of gases from the chamber. The samples were then put on the vacuum bottles. In this research, Gas Chromatography Shimadzu 14-B and Chromatopac Shimadzu C-R6A were used to determine the $\mathrm{CO}_{2}$ and $\mathrm{CH}_{4}$ emissions. The emissions were calculated by using following equation (Boer et al., 1996):

$$
\begin{gathered}
\Phi_{\mathrm{M}}=\left\{\left(\delta\left[\mathrm{CO}_{2} / \mathrm{CH}_{4}\right] \delta \mathrm{t} \times \mathrm{h}_{\mathrm{U}} \times 16.123(44.01) \times 273.2 \times\right.\right. \\
\left.(60 / 22.410)) /\left(\mathrm{t}_{\mathrm{U}}+273.2\right) \mathrm{mg} \mathrm{m}^{-2} \mathrm{~h}^{-1}\right\}
\end{gathered}
$$

Where: $\delta\left[\mathrm{CO}_{2} / \mathrm{CH}_{4}\right] \delta \mathrm{t}=$ change of the concentrations of $\mathrm{CO}_{2}$ and $\mathrm{CH}_{4}$ in chamber after the periode of $t$ minute $(\mathrm{s}) ; \mathrm{h}_{\mathrm{U}}$ $=$ the height of chamber; $t_{U}=$ the average of air temperature in chamber; Value of $16.123=$ the weight of $\mathrm{CH}_{4}$ molecule, $44.01=$ weight of $\mathrm{CO}_{2}$; Value of $273.2=$ temperature in Kelvin; 22.41 = volume of gas molecule; and Value of 60 meants 60 minutes ( 1 hour). Other parameters were observed between: plant height 42 days after planting, the maximum tillers and productive tillers number, straw dry weight and grain dry milled weight.

\section{RESULTS AND DISCUSSION}

\section{A. Chemical Composition of Peat}

Several chemical characteristics of peats (Table 1) interesting to discuss. Although the total $\mathrm{N}$ is high, but the $\mathrm{C} / \mathrm{N}$ ratio is very high, this means that $\mathrm{N}$ is a structural constituent of peat organic matter that is available $\mathrm{N}$ is low, thereby becoming a limiting factor for plant growth. cation exchange capacity (CEC) value is very high, but base saturation (BS) is very low, thus inhibiting the provision of nutrients, mainly $\mathrm{K}, \mathrm{Ca}$ and $\mathrm{Mg}$ for plants.

The situation got worst because exchangeable $\mathrm{Na}, \mathrm{K}, \mathrm{Ca}$ and $\mathrm{Mg}$ is very low and therefore inhibit the growth and yield. Availability and total micro nutrient content are very low except for $\mathrm{Fe}$ is quite high, causing micro nutrient deficient for plants. According to Simbolon (2009) peat soil $\mathrm{pH}$ is very low, the availability of macro $(\mathrm{N}, \mathrm{P}, \mathrm{K}, \mathrm{Ca}$ and $\mathrm{Mg})$ nutrient are low and deficient micro $(\mathrm{Cu}, \mathrm{Zn}, \mathrm{Mn}, \mathrm{Fe}, \mathrm{B}$ and Mo) nutrient, CEC is very high but BS is low. Where the availability of $\mathrm{Cu}$ is the lowest compared to other micro nutrient because the $\mathrm{Cu}$ bounds to organic compounds functional groups such as carboxyl $(\mathrm{COOH})$ and phenolic ($\mathrm{OH}$ ) to form organo-cation complex of $\mathrm{Cu}$ (chelate) that are not available for plants.

Several chemical charateristics (macro and micro nutrient) contained in drges quickly available in peat, because hasil the extraction with $2 \%$ citric acid is almost equal to the extraction with mineral acids $\left(\mathrm{HClO}_{4}\right.$ and $\mathrm{HNO}_{3}$ pa) (Table 2). Dissociation of $\mathrm{H}$ ions from organic compounds cause the concentration of $\mathrm{H}^{+}$ions on peat soil is very high, $\mathrm{H}^{+}$ ions can hydrolyze dregs so that it dissolves quickly. Results of analysis of havy metal content in the drges $(\mathrm{Pb}$, $\mathrm{Cd}, \mathrm{As}, \mathrm{Hg}, \mathrm{Co}, \mathrm{Ni}, \mathrm{Cr}, \mathrm{Ag}, \mathrm{Sn}$ and $\mathrm{Mo}$ ) total are very low (Table 3), are not including those identified B3 waste so it can be dumped in landfill light weight category.

TABLE I

CHEMICAL CHARACTERITICS AND ASH CONTENT OF PEAT SOILS USED IN

\begin{tabular}{|c|c|c|c|}
\hline Chemical characteristics & Value & $\begin{array}{c}\text { Chemical characteristics and } \\
\text { ash content }\end{array}$ & Value \\
\hline $\mathrm{pH} \mathrm{H}_{2} \mathrm{O}(1: 5)$ & 3.2 & Base Saturation $(\%)$ & 6 \\
\hline $\mathrm{pH} \mathrm{KCl}(1: 5)$ & 3.0 & Micro nutrient (Extract. DTPA) & \\
\hline Organic-C $\left(\mathrm{g} \mathrm{kg}^{-1}\right)$ & 437.3 & $\mathrm{Fe}(\mu \mathrm{g} / \mathrm{g})$ & 475 \\
\hline Total-N $\left(\mathrm{g} \mathrm{kg}^{-1}\right)$ & 6.5 & $\operatorname{Mn}(\mu \mathrm{g} / \mathrm{g})$ & 1 \\
\hline $\mathrm{C} / \mathrm{N}$ ratio & 67.28 & $\mathrm{Cu}(\mu \mathrm{g} / \mathrm{g})$ & 2 \\
\hline Exc.Ca $(\mathrm{cmol}(+) / \mathrm{kg})$ & 2.27 & $\mathrm{Zn}(\mu \mathrm{g} / \mathrm{g})$ & 2 \\
\hline Exc.Mg $(\mathrm{cmol}(+) / \mathrm{kg})$ & 0.68 & Micro nutrient (Extract. $\mathrm{HNO}_{3}$ & \\
\hline Exc.K $(\mathrm{cmol}(+) / \mathrm{kg})$ & 0.22 & $\left.+\mathrm{HClO}_{4} \mathrm{pa}\right)$ & \\
\hline Exc.Na $(\mathrm{cmol}(+) / \mathrm{kg})$ & 0.26 & $\mathrm{Fe}(\mu \mathrm{g} / \mathrm{g})$ & 3606 \\
\hline $\mathrm{P}_{2} \mathrm{O}_{5}(\mu \mathrm{g} / \mathrm{g})($ Bray I) & 135.4 & $\operatorname{Mn}(\mu \mathrm{g} / \mathrm{g})$ & 12.3 \\
\hline $\mathrm{P}_{2} \mathrm{O}_{5}(\mathrm{mg} / 100 \mathrm{~g})(\mathrm{HCl} 25 \%)$ & 32 & $\mathrm{Cu}(\mu \mathrm{g} / \mathrm{g})$ & 3.1 \\
\hline \multirow[t]{2}{*}{$\mathrm{CEC}(\mathrm{cmol}(+) / \mathrm{kg})$} & 72.45 & $\mathrm{Zn}(\mu \mathrm{g} / \mathrm{g})$ & 4.8 \\
\hline & & Ash content $(\%)$ & 15.89 \\
\hline
\end{tabular}
THIS RESEARCH 
TABLE III

CHEMICAL CHARACTERIZATION AND MOISTURE OF DREGS

\begin{tabular}{|c|c|c|c|}
\hline Chemical characteristics & Value & $\begin{array}{c}\text { Chemical } \\
\text { characteristics and ash } \\
\text { content }\end{array}$ & Value \\
\hline $\mathrm{pH} \mathrm{H}_{2} \mathrm{O}(1: 5)$ & 9.3 & $\begin{array}{l}\text { Macro nutrient (Extract. } \\
\text { Citric Acid 2\%) }\end{array}$ & \\
\hline $\begin{array}{l}\text { Macro nutrient (Extract. } \\
\mathrm{HClO}_{4} \& \mathrm{HNO}_{3} \text { pa) }\end{array}$ & & $\mathrm{P}_{2} \mathrm{O}_{5}\left(\mathrm{~g} \mathrm{~kg}^{-1}\right)$ & 1.8 \\
\hline $\mathrm{P}_{2} \mathrm{O}_{5}\left(\mathrm{~g} \mathrm{~kg}^{-1}\right)$ & 2.0 & $\mathrm{~K}_{2} \mathrm{O}\left(\mathrm{g} \mathrm{kg}^{-1}\right)$ & 3.1 \\
\hline $\mathrm{K}_{2} \mathrm{O}\left(\mathrm{g} \mathrm{kg}^{-1}\right)$ & 3.1 & $\mathrm{CaO}\left(\mathrm{g} \mathrm{kg}^{-1}\right)$ & 409.7 \\
\hline $\mathrm{CaO}\left(\mathrm{g} \mathrm{kg}^{-1}\right)$ & 410.3 & $\operatorname{MgO}\left(\mathrm{g} \mathrm{kg}^{-1}\right)$ & 23.2 \\
\hline $\operatorname{MgO}\left(\mathrm{g} \mathrm{kg}^{-1}\right)$ & 23.9 & $\mathrm{Na}\left(\mathrm{g} \mathrm{kg}^{-1}\right)$ & 25.9 \\
\hline $\mathrm{Na}\left(\mathrm{g} \mathrm{kg}^{-1}\right)$ & 26.8 & $\mathrm{~S}\left(\mathrm{~g} \mathrm{~kg}^{-1}\right)$ & \\
\hline $\mathrm{S}\left(\mathrm{g} \mathrm{kg}^{-1}\right)$ & 7.2 & $\begin{array}{l}\text { Micro nutrient (Extract. } \\
\text { Citric Acid 2\%) }\end{array}$ & 6.4 \\
\hline $\begin{array}{l}\text { Micro nutrient (Extract. } \\
\mathrm{HCLO}_{4} \& \mathrm{HNO}_{3} \text { pa) }\end{array}$ & & $\mathrm{Fe}\left(\mu \mathrm{g} \mathrm{g}^{-1}\right)$ & 3244 \\
\hline $\mathrm{Fe}\left(\mu \mathrm{g} \mathrm{g}^{-1}\right)$ & 5000 & $\operatorname{Mn}\left(\mu g^{-1}\right)$ & 914 \\
\hline $\operatorname{Mn}\left(\mu \mathrm{g} \mathrm{g}^{-1}\right)$ & 989 & $\mathrm{Cu}\left(\mu \mathrm{g} \mathrm{g}^{-1}\right)$ & 105 \\
\hline $\mathrm{Cu}\left(\mu \mathrm{g} \mathrm{g}^{-1}\right)$ & 127 & $\mathrm{Zn}\left(\mu \mathrm{g} \mathrm{g}^{-1}\right)$ & 206 \\
\hline $\mathrm{Zn}\left(\mu \mathrm{g} \mathrm{g}^{-1}\right)$ & 224 & moisture $(\%)$ & 15 \\
\hline
\end{tabular}

TABLE IIIII

HEAVY METAL CONTENT OF DREGS

\begin{tabular}{|l|c|l|c|}
\hline \multicolumn{1}{|c|}{ Chemical characteristics } & Value & \multicolumn{1}{c|}{ Chemical characteristics } & Value \\
\hline Extraction $\left(\mathrm{HClO}_{4}+\right.$ & & Extraction (citric acid & \\
$\left.\mathrm{HNO}_{3} \mathrm{pa}\right)$ & & $2 \%)$ & \\
$\mathrm{Pb}\left(\mu \mathrm{g} \mathrm{g}^{-1}\right)$ & 8.9 & $\mathrm{~Pb}\left(\mu \mathrm{g} \mathrm{g}^{-1}\right)$ & 0.1 \\
$\mathrm{Cd}\left(\mu \mathrm{g} \mathrm{g}^{-1}\right)$ & 0.2 & $\mathrm{Cd}\left(\mu \mathrm{g} \mathrm{g}^{-1}\right)$ & $\mathrm{nm}$ \\
$\mathrm{As}\left(\mu \mathrm{g} \mathrm{g}^{-1}\right)$ & 3.8 & $\mathrm{As}\left(\mu \mathrm{g} \mathrm{g}^{-1}\right)$ & $\mathrm{nm}$ \\
$\mathrm{Hg}\left(\mu \mathrm{g} \mathrm{g}^{-1}\right)$ & 0.23 & $\mathrm{Hg}\left(\mu \mathrm{g} \mathrm{g}^{-1}\right)$ & $\mathrm{nm}$ \\
$\mathrm{Co}\left(\mu \mathrm{g} \mathrm{g}^{-1}\right)$ & 1.7 & $\mathrm{Co}\left(\mu \mathrm{g} \mathrm{g}^{-1}\right)$ & 1.5 \\
$\mathrm{Ni}\left(\mu \mathrm{g} \mathrm{g}^{-1}\right)$ & 98.6 & $\mathrm{Ni}\left(\mu \mathrm{g} \mathrm{g}^{-1}\right)$ & 98.5 \\
$\mathrm{Cr}\left(\mu \mathrm{g} \mathrm{g}^{-1}\right)$ & 167 & $\mathrm{Cr}\left(\mu \mathrm{g} \mathrm{g}^{-1}\right)$ & 120 \\
$\mathrm{Se}\left(\mu \mathrm{g} \mathrm{g}^{-1}\right)$ & 355 & $\mathrm{Se}\left(\mu \mathrm{g} \mathrm{g}^{-1}\right)$ & 169 \\
$\mathrm{Ag}\left(\mu \mathrm{g} \mathrm{g}^{-1}\right)$ & $\mathrm{nm}$ & $\mathrm{Ag}\left(\mu \mathrm{g} \mathrm{g}^{-1}\right)$ & $\mathrm{nm}$ \\
$\mathrm{Sn}\left(\mu \mathrm{g} \mathrm{g}^{-1}\right)$ & $\mathrm{nm}$ & $\mathrm{Sn}\left(\mu \mathrm{g} \mathrm{g}^{-1}\right)$ & $\mathrm{nm}$ \\
$\mathrm{Mo}\left(\mu \mathrm{g} \mathrm{g}^{-1}\right)$ & $\mathrm{nm}$ & $\mathrm{Mo}\left(\mu \mathrm{g} \mathrm{g}^{-1}\right)$ & $\mathrm{nm}$ \\
\hline
\end{tabular}

\section{B. The effect of application of ameliorant dregs in the peat} at saturation and unsaturation condition on growth and yield of rice

The aplication of dregs improves plant growth (plant height, number of maximum tillers, number of productive tillers and weight of dry straw ) and increase the yield of rice (weight of dry milled grain) compared without dreg both at unsaturated condition and saturated conditions (Table 4 and Fig. 1). Rice can not grow well in peat, which is not applied ameliorant dreg, the cause is the low nutrient availability and high content of phenolic acids that are toxic to plants. Tim Sintesis Kebijakan (2008) reports that rice plants grown in peat soil with a thickness of over $2 \mathrm{~m}$ deficient $\mathrm{Cu}$ failed to form a grain. The peat composition is dominated by lignin of $65 \%$ to $80 \%$ and $78 \%$ to $93 \%$ for the peats of Jambi and Central Kalimantan respectively (Sabiham, 2010), and $71,46 \%$ for the peats of Riau (Nelvia, 2009). Orlov (1995) showed the processes of lignin disintegration that result in several derivate phenolic acids. Phenolic acids are more phytotoxic for plants and causes stunted plant growth (Tsutuki, 1984; Stevens, et al., 1994; Dohong and Sabiham, 2001), influence the biochemical and physiological processes of plants and nutrients uptake by plant influence the biochemical and physiological processes of plants and nutriens uptake by plent (Driessen, 1978). Tsutsuki et al.
(1994) stated that the concentration of phenolic acids at the range of 0.6 to $3.0 \mathrm{mM}$ could hamper the root growth of rice up to $50 \%$. Todano et al. (1992) reported that derivate phenolic acids, such as ferulic, synapic, p-cumaric, and phydroxybenzoic acids are phytotoxic for rice, particularly during the first stage of plant growth. He also mentioned that ferulic acid in peat is more toxic compared to the other derivate phenolic acids.

TABLE IVV

THE EFFECT OF AMELIORANT DREGS IN THE PEAT ON THE PLANT HEIGHT, MAXIMUM AND PRODUCTIVE TILLERS NUMBER AND WEIGHT OF DRY STRAW AND MILLED DRY GRAIN OF RICE

\begin{tabular}{|c|c|c|c|c|c|c|}
\hline $\begin{array}{c}\text { Water } \\
\text { condition }\end{array}$ & $\begin{array}{c}\text { Dregs } \\
\left(\text { ton ha }^{-\mathbf{1}}\right)\end{array}$ & $\begin{array}{c}\text { Plant } \\
\text { height } \\
(\mathbf{c m})\end{array}$ & $\begin{array}{c}\text { maximm } \\
\text { tillers } \\
\left(\text { number }_{\left.\text {pot }^{-1}\right)}\right.\end{array}$ & $\begin{array}{c}\text { productive } \\
\text { tillers } \\
\left(\text { number }_{\left.\text {pot }^{-1}\right)}\right.\end{array}$ & $\begin{array}{c}\text { dry } \\
\text { straw } \\
\left(\mathbf{g}_{\text {pot }^{-1}}\right)\end{array}$ & $\begin{array}{c}\text { milled } \\
\text { dry } \\
\text { grain } \\
\left(\mathbf{g}_{\text {pot }^{-1}}\right)\end{array}$ \\
\hline \multirow{4}{*}{ Saturated } & 0 & $47 \mathrm{c}$ & $20 \mathrm{~d}$ & $17 \mathrm{c}$ & $20 \mathrm{c}$ & $20.0 \mathrm{c}$ \\
\cline { 2 - 7 } & 10 & $66 \mathrm{a}$ & $33 \mathrm{c}$ & $23 \mathrm{bc}$ & $42 \mathrm{~b}$ & $35.4 \mathrm{a}$ \\
\cline { 2 - 7 } & 15 & $67 \mathrm{a}$ & $45 \mathrm{ab}$ & $31 \mathrm{a}$ & $61 \mathrm{a}$ & $54.8 \mathrm{~b}$ \\
\cline { 2 - 7 } & 20 & $67 \mathrm{a}$ & $47 \mathrm{a}$ & $30 \mathrm{a}$ & $62 \mathrm{a}$ & $54.9 \mathrm{~b}$ \\
\hline \multirow{3}{*}{$\begin{array}{c}\text { Un- } \\
\text { saturated }\end{array}$} & 0 & $52 \mathrm{~b}$ & $20 \mathrm{~d}$ & $19 \mathrm{c}$ & $27 \mathrm{c}$ & $29,8 \mathrm{c}$ \\
\cline { 2 - 7 } & 10 & $64 \mathrm{a}$ & $36 \mathrm{abc}$ & $31 \mathrm{a}$ & $43 \mathrm{~b}$ & $53,7 \mathrm{~b}$ \\
\cline { 2 - 7 } & 15 & $68 \mathrm{a}$ & $35 \mathrm{bc}$ & $28 \mathrm{ab}$ & $46 \mathrm{~b}$ & $53,0 \mathrm{~b}$ \\
\cline { 2 - 7 } & 20 & $66 \mathrm{a}$ & $36 \mathrm{abc}$ & $28 \mathrm{ab}$ & $52 \mathrm{~b}$ & $45.3 \mathrm{a}$ \\
\hline
\end{tabular}

Note: The numbers in the same columns which followed the same lowercase letter are not significantly different at $\alpha 5 \%$ DNMRT test.

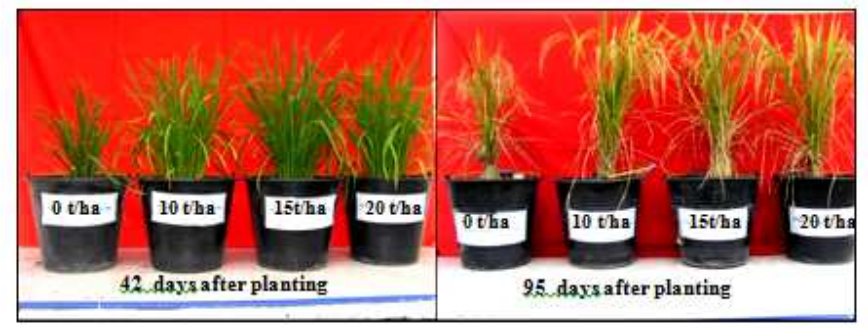

a. Unsaturation condition

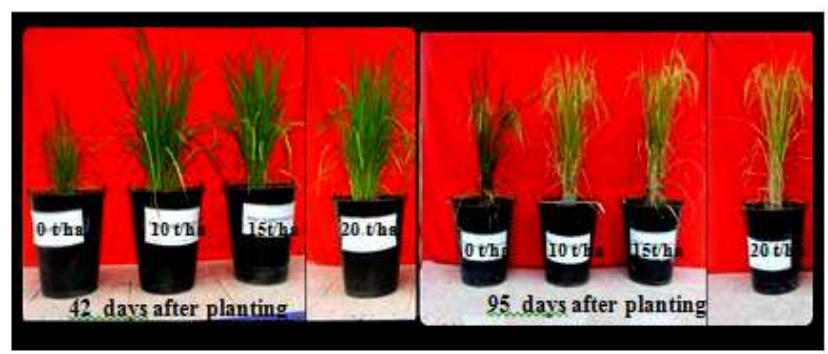

b. Saturation condition

Fig. 1. The growth of rice at vegetative and generative phase in unsaturated (a) and saturated condition (b)

The application dreg $10 \mathrm{t} \mathrm{ha}^{-1}$ increase the maximum number of tillers, number of productive tillers, straw dry weight and the weight of milled rice by $65,35.29,110$ and $75 \%$, respectively compared without dreg on saturated condition, whereas the increase is greater unsaturated conditions about $80,63,59$ and $80 \%$, respectively (Table 4). This is due to the improvement of the condition of the peat soil chemistry by ameliorant dreg in the form increase nutrient availability and decreasing the solubility of phenolic acids. Its caused by the dregs contain macro (P, K, Ca, $\mathrm{Mg}$, $\mathrm{S})$ and micro $(\mathrm{Fe}, \mathrm{Cu}, \mathrm{Zn}, \mathrm{Mn}, \mathrm{Mo}$ ) nutrients or polivalen cations and quickly available in peat (Table 2). Reduced 
solubility of phenolic acids occurs due to the formation of complex compounds of phenolic acids with cations $\mathrm{Fe}, \mathrm{Cu}$, $\mathrm{Zn}, \mathrm{Mn}, \mathrm{Ca}$ and $\mathrm{Mg}$ are dissolved from the dreg. Sabiham (2010) reported that the concentration of derivate phenolic acids namely: ferulic, syanapic, p-cumaric, vanilic, syringic and p-hydroxybenzoic acids in peats decreased with the addition of mineral soil or basic slag, or the ombination of both materials.

\section{The effect of application of ameliorant dregs in the peat soil at unsaturation and saturation condition on carbon emission}

The Cabon-release in the forms of $\mathrm{CO}_{2}$ and $\mathrm{CH}_{4}$ fluxes in saturated conditions is smaller than unsaturated conditions, the application of dregs $10 \mathrm{t} \mathrm{ha}^{-1}$ in saturated condition can reduce $\mathrm{CO}_{2}$ emissions about $18.19 \%$ and $\mathrm{CH}_{4}$ emissions about $93.71 \%$ compared without dreg, otherwise the application dreg 10,15 and $20 \mathrm{t} \mathrm{ha}^{-1}$ in unsaturated conditions increase the production of $\mathrm{CO}_{2}$ and $\mathrm{CH}_{4}$ (Table 5). Unsaturated conditions (aerobic) conditions where the peat is available high due to the high diffusion, so the more active microorganisms both the type and amount of the anaerobic conditions, the result would accelerate the process of decomposition of organic matter. While in saturated conditions (anaerobic) only anaerobic bacteria can live, thus $\mathrm{CO}_{2}$ as a result of respiration and decomposition of organic matter will be higher in unsaturated than saturated conditions. Boer et al. (1996) reported that the amount of $\mathrm{CH}_{4}$ emission rate depends on soil water conditions, flooded peatlands emit $\mathrm{CH}_{4}$ greater than the land is not flooded. Research by Sabiham and Sulistyono (2000) in the laboratory showed that the highest $\mathrm{CO}_{2}$ production obtained in aerobic incubation and significantly different with anaerobic incubation, while the highest $\mathrm{CH}_{4}$ production was obtained on anaerobic incubation and significantly different with aerobic incubation.

TABLE V

THE EFFECT OF APPLICATION OF AMELIORANT DREGS IN THE PEAT SOIL AT SATURATION AND UNSATURATION CONDITION ON THE CO2 AND CH4 PRODUCTION

\begin{tabular}{|c|c|c|c|}
\hline $\begin{array}{c}\text { Water } \\
\text { condition }\end{array}$ & $\begin{array}{c}\text { Dregs } \\
\left(\text { ton } \text { ha }^{-1}\right)\end{array}$ & $\begin{array}{l}\mathrm{CO}_{2} \text { production } \\
\left(\mathrm{mg} \mathrm{pot}^{-1} \mathbf{h}^{-1}\right)\end{array}$ & $\begin{array}{l}\mathrm{CH}_{4} \text { production } \\
\left(\mathrm{mg} \mathrm{pot}^{-1} \mathbf{h}^{-1}\right)\end{array}$ \\
\hline \multirow{4}{*}{ saturation } & 0 & $8.12 \mathrm{a}$ & $29.70 \mathrm{a}$ \\
\hline & 10 & $6.64 \mathrm{~b}$ & $1.87 \mathrm{c}$ \\
\hline & 15 & $8.38 \mathrm{a}$ & $3.07 \mathrm{bc}$ \\
\hline & 20 & $7.31 \mathrm{~b}$ & $2.68 \mathrm{bc}$ \\
\hline \multirow{4}{*}{ unsaturation } & 0 & $18.72 \mathrm{~b}$ & $6.69 \mathrm{~b}$ \\
\hline & 10 & $29.71 \mathrm{~b}$ & $7.61 \mathrm{~b}$ \\
\hline & 15 & $52.57 \mathrm{a}$ & $19.39 \mathrm{a}$ \\
\hline & 20 & $15.64 \mathrm{~b}$ & $5.78 \mathrm{~b}$ \\
\hline
\end{tabular}

Note: The numbers in the same columns which followed the same lowercase letter are not significantly different at $\alpha 5 \%$ DNMRT test

The decrease in emissions of $\mathrm{CO}_{2}$ and $\mathrm{CH}_{4}$ in the saturated condition by administering dreg $10 \mathrm{t} \mathrm{ha}^{-1}$ is because dreg containing polyvalent cations and release such as $\mathrm{Fe}$ and $\mathrm{Cu}$ to the soil (Table 2). $\mathrm{Fe}$ and $\mathrm{Cu}$ cations form complex compounds between organic compounds with Fe or
$\mathrm{Cu}$ cations, that is stable so it can not be decomposed by microbes. Giving dreg with the higher dose (15-20) has stimulate more rapid decomposition of organic matter, especially in unsaturated conditions, while the formation of complex organic compounds-metal running over time, The result is an increase in emissions of $\mathrm{CO}_{2}$ and $\mathrm{CH}_{4}$. Research Sabiham and Sulistyono (2000) in the laboratory showed that administration of $\mathrm{Fe}^{3+}$ cations as much as $5 \%$ maximum erapan can reduce $22.94 \% 23.01 \% \mathrm{CO}_{2}$ and $\mathrm{CH}_{4}$ in the peat soil of the area Dendang Jambi and $27.67 \%$ and $32.97 \% \mathrm{CO}_{2}$ $\mathrm{CH}_{4}$ in the peat soil of the Sampit, Central Kalimantan. The addition of 15 and $30 \mathrm{~g}$ of $\mathrm{Fe}(\mathrm{OH})_{3}$ per $\mathrm{kg}$ of soil to lower the total $\mathrm{CH}_{4}$ emissions by $43 \%$ and $84 \%$ during the growth of rice (Jackel and Schnell 2000). Where the stability of complexes between humic acid-metal getting weaker in the order of $\mathrm{Al}^{3+}>\mathrm{Fe}^{3+}>\mathrm{Cu}^{2+}>\mathrm{Mn}^{2+}>\mathrm{Zn}^{2+}>>\mathrm{Mg}^{2+}>\mathrm{Ca}^{2+}$ (Tan, 2003).

\section{CONCLUSIONS}

The application of dregs improves plant growth and increase the yield of rice compared without dreg both at unsaturated condition and saturated conditions. The application dreg $10 \mathrm{t} \mathrm{ha}^{-1}$ increase the maximum number of tillers, number of productive tillers, straw dry weight and the weight of milled rice by $65,35,110$ and $75 \%$, respectively compared without dreg on saturated condition, whereas the increase is greater unsaturated conditions about 80, 63, 59 and $80 \%$, respectively.

The Cabon-release in the forms of $\mathrm{CO}_{2}$ and $\mathrm{CH}_{4}$ fluxes in saturated conditions is smaller than unsaturated conditions, the application of dregs $10 \mathrm{t} \mathrm{ha}^{-1}$ in saturated condition can reduce $\mathrm{CO}_{2}$ and $\mathrm{CH}_{4}$ emissions about $18.19 \%$ and $93.71 \%$ compared without dreg, otherwise the application dreg 10-20 $\mathrm{t}$ ha ${ }^{-1}$ increase the production of $\mathrm{CO}_{2}$ and $\mathrm{CH}_{4}$ in unsaturated conditions.

\section{REFERENCES}

[1] Boer, R., I. Nasution, I. Las and A. Bey. 1996. Emisi metan dari lahan gambut sejuta hektar, Kalimantan Tengah (Methane emission from the one-million-hectare peatlands, Central Kalimantan). J. Agromet 12 (1\&2) 1996/1997. Pp. 31-38.

[2] Dohong, S. S. Sabiham, 2001. Several derivate of phenolic acids on Central Kalimantan on different environment of peat formation. Agrista. Vol 5 (3): 197-203.

[3] Driessen, P.M. 1978. Peat soils. In: IRRI. Soil and rice. IRRI. Los Banos. Philippines. Pp: 763-779.

[4] Hooijer, A, Page, S., Canadell, J., Silvius, M. Kwidjjk, J. Wosteten, H. and Jauhiainen J. 2010. Curren and future CO2 emission from drained peatlands in Southeast Asia. Biogeosciences, 7, 1505-1514

[5] Jackel, U and S. Schnell. 2000. Suppression of methane emission from rice paddies by ferric iron fertilization. Soil Biology \& Biochemistry. 32:1811-1814.

[6] Nelvia, Rosmimi, Rini and R. Frizdew. 2008. Peningkatan produktivitas lahan gambut dengan pemberian amelioran dregs (Limbah bagian Recauticizing pabrik pulp) berkadar kation polivalen tinggi. Dalam Prsiding Semiloka Nasional. Departemen Ilmu Tanah dan Sumberdaya Lahan IPB. Bogor. 22-23 Desember 2008. Pp 497506.

[7] --------. 2009. Kandungan fosfor tanaman padi dan emisi karbon tanah gambut yang diaplikasi dengan amelioran Fe3+ dan fosfat alam pada beberapa tingkat pemberian air. Jurnal Tanah tropika Vol. 14 (3): 195-204.

[8] Orlov, D.S. 1995. Humic substancess of soils and general theory of humicfication. A.A. Balkema Publ. USA. 
[9] Sabiham, S. and N.B.E. Sulistyono. 2000. Kajian beberapa sifat inheren dan perilaku gambut: Kehilangan karbondioksida (CO2) dan metana (CH4) melalui proses reduksi-oksidasi. J. Tanah Tropika. V (10): $127-135$.

[10] 2010. Properties of Indonesian peat in relation to the chemistry of carbon emission. In: Proceeding of International Workshop on Evaluation and Sustainable Management of Soil Carbon Sequestration in Asian Countries. Pp: 205-216

[11] Simbolon, H. 2009. Peat swamp forest ecosystem: An important ecosystem on regional land use planning. In Scientific Exploration and Sustainable Management of Peat Land Resources in Giam Siak Kecil-Bukit Batu Biosphere reserve. Riau. Pp: 165-174.

[12] Stevens, D.P., M.J. Mclaughlin and A.M. Alston. 1994. Are Aluminum-Fluoride complexes Phytotoxic. 15th World Congress of Soil Science. Acapulco. Mexico

[13] Tadano, K. Yonebayashi and N.Saito 1992. Effect of phenolic acids on the growth and occurrence of sterility in crop plants. Pp:358-369. In: K.Kyuma, P.Vajarnsorn and A.Zakaria (eds) Coastal lowland ecosystems in southerm Thailand and Malaysia. Showado-printing co. Skyoku-Kyoto

[14] Tan, K.H. 2003. Humic Matter in the soil and the environment; Principles and Controversies. Marcel Dekker, Inc. new York. USA. P 359.

[15] Tim Sintesis Kebijakan. 2008. Pemanfaatan dan konservasi ekosistem lahan rawa gambut di Kalimantan. Pengembangan Inovasi Pertanian 1 (2): 149-156.

[16] Tsutsuki, K. 1984. Volatile products and low molecular-weight products of the anaerobic decomposition of organic matter. pp :329343. International Rice Research Institute, Soil Organic Matter.

[17] Wahyunto, Ritung S., Suparto and Subagjo H. 2005. Peat land Distribution and Carbon Content in Sumatera and Kalimantan. Wetland International- Indonesia Program and Wildlife Habitat Canada (WHC). Bogor-Indonesia

[18] Yagi, K and K. Minami. 1990. Effect of organic matter application on methane emission from some Japanese paddy field. Soil Sci. Plant Nutr. 36(4):599-610. 